\title{
STUDI JENIS BURUNG YANG DIPERDAGANGKAN DI KOTA KETAPANG
}

\author{
(Study of Trade Bird Species In The City of Ketapang)
}

\author{
Juhardiansyah, H. Erianto, H. M. Idham \\ Fakultas Kehutanan Universitas Tanjungpura. Jalan Imam Bonjol Pontianak 78124 \\ E-mail : Juhardiansyah28@gmail.com
}

\begin{abstract}
This study aims to explore information on the types of birds that are traded, to know the description of the location of birds originating, to know the status of protected species traded, to know the locations of shelters and the sale of traded birds, to know the number and prices of birds traded. This research was conducted in Ketapang City for 10 days effectively in the field, with the research method in field data collection using snowball sampling technique, namely determining key respondents to then determine other respondents who also knew the relevant information from previous respondents. The results of the data obtained at the time of the study were 267 individuals from 31 species of birds traded. The origin of the traded birds is a specific natural catch in the Jelai Hulu sub-district, Tumbang Titi sub-district, Kendawangan subdistrict, Sandai sub-district, Laur sub-district, Matan Hilir Selatan sub-district, Matan Hilir Utara sub-district, Muara Pawan sub-district, and Teluk Batang sub-district and Kayong Utara regency. There are 11 protected bird species as a whole belonging to 15 tribes (families). Of these types, they fall into the protected category according to the Indonesian Law. Birds are in the category of Apendix II CITES and birds are listed in the IUCN Red List category. As for the research on the trading location there were 10 respondents 2 people in the hunter category and 8 bird shops / traders. while the most types of birds sold per type are Kacer (copshycus saularis) as many as 50 Tails / Individual, Murai batu (Copsychus malabaricus) and Serindit (Loriculus galgulus) as many as 44 Tails / Individuals.
\end{abstract}

Keyword: Bird Species, Bird Trade, Ketapang

\section{PENDAHULUAN}

Perdagangan satwa liar adalah salah satu ancaman konservasi utama di Asia Tenggara (Nijman, 2010), dan Indonesia dikenal akan tingginya tingkat perdagangan berbagai spesies satwa liar illegal dan tidak berkelanjutan (Shepherd, 2006; Stengel et.al, 2011; Nellemann et.al, 2014). Keragaman yang tinggi jenis burung di Kalimantan Barat juga ikut terancam kepunahan oleh berbagai kegiatan manusia seperti perburuan dan penangkapan untuk perdagangan. Perdagangan burung liar menjadi ancaman yang serius bagi kelangsungan hidup burung di alam karena burung yang diperdagangkan berasal dari tangkapan alam dan sedikit burung dari penangkaran. Burung merupakan hewan peliharaan yang paling popular dibandingkan hewan lainnya di kabupaten Ketapang Provinsi Kalimantan Barat. Burung sangat diminati masyarakat sebagai hewan peliharaan karena keindahan warna bulu dan suaranya. Burung juga termasuk salah satu komoditas perdagangan, burung disuplai kebeberapa daerah luar 
kalimanatan barat seperti Semarang, Surabaya dan Jakarta.

Berbagai macam alasan yang melatar belakangi orang memelihara dan memperdagangkan burung. Maraknya lomba dan kontes burung berkicau di Kalimantan Barat, mengakibatkan permintaan terhadap burung berkicau semakin meningkat membawa dampak sosial, yang memiliki nilai ke-unikan tersendiri bagi para pencinta burung kicau dan dampak ekonomi sebagai income masyarakat di berbagai daerah di Kalimantan Barat. Dalam kehidupan sosial dikalangan para pencinta burung kicau, burung kicau dijadikan sebagai representasi status seseorang dalam masyarakat. Burung kicau dalam konteks sosial memiliki pemaknaan atau simbol terhadap status sosial dan ekonomi suatu masyarakat khususnya para pencinta dan penggemar burung kicau di Kabupaten Ketapang. Burung kicau mampu memberikan pendapatan terhadap masyarakat dimana penghasilannya tersalurkan pula terhadap para penjual pakan dan aksesori seperti sangkar, dan aksesori lainnya. Seiring meningkatnya frekuensi lomba-lomba burung kicau yang diselenggarakan di kabupaten Ketapang, terkadang pencinta burung kicau juga menghadiri perlombaan dan kontes di kabupaten/kota dalam wilayah Kalimantan Barat.

Banyaknya faktor yang menjadi ancaman terhadap keanekaragaman burung tidak boleh dibiarkan oleh karena itu dibutuhkan perhatian dan usaha dari berbagai pihak untuk menjaga dan melestarikan satwa liar tersebut. Namun, semua rencana dan usaha menyelamatkan burung-burung liar dari kepunahan tersebut tidak dapat dikembangkan tanpa studi jenis, populasi, ancaman dan tindakan konservasi yang efektif. Studi burung yang diperdagangkan di Kota Ketapang adalah pengumpulan data yang dapat mengungkapkan kecenderungan yang signifikan dalam faktor-faktor yang menarik akan sangat mendukung dan penting dalam menilai kecenderungan populasi jangka panjang dan dalam menyusun rencana-rencana program konservasi burung nantinya.

\section{Masalah Penelitian}

Jenis burung apa saja yang diperdagangkan, dari mana burungburung yang diperdagangkan berasal, apa saja jenis burung yang dilindungi, kemana distribusi burung yang diperdagangkan, serta berapa banyak burung yang diperdagangkan dan bagaimana potensi nilai ekonomi burung yang diperdagangkan terhadap pendapatan.

\section{Tujuan}

Adapun tujuan dari penelitian ini adalah untuk mendata perdagangan burung dengan mengetahui jenis, asal usul burung, status perlindungan burung, lokasi - lokasi penampungan dan distribusi penjualan burung, serta mengetahui jumlah dan harga burung yang diperdagangkan.

\section{Manfaat}

Tersedianya informasi mengenai jenis burung yang dipedagangkan, 
adanya gambaran asal usul burung yang diperdagangkan, tersedianya informasi mengenai status perlindungan jenis burung yang diperdagangkan, tersedianya informasi mengenai lokasilokasi penampungan dan penyebaran burung yang diperdagangkan, serta tersedianya informasi jumlah dan harga burung yang diperdagangkan.

\section{METODE PENELITIAN}

Penelitian ini dilaksanakan pada tanggal 18 September - 27 September 2018 di Kota Ketapang selama 10 Hari di lapangan. Alat dan bahan yang digunakan untuk pengambilan data dilapangan terdiri dari : Buku pedoman Bird Of Borneo, Mackinnon SKJB, Tape Recorder, Alat Tulis, Kamera sedangkan bahan yang digunakan Kuesioner, untuk responden terpilih, Tally sheet, untuk daftar catatan di lapangan.

Objek dalam pengambilan data adalah: masyarakat yang terlibat langsung dalam kegiatan perdagangan burung yaitu pemburu, penampung dan pedagang burung di Kota Ketapang, burung yang dimanfaatkan untuk diperjual belikan. Pengambilan data di lapangan penelitian ini bersifat deskriptif kualitatif dengan menggunakan teknik snowball sampling (Bernard, 2002), dengan cara menentukan responden kunci untuk kemudian menentukan responden lain yang juga mengetahui informasi terkait dari responden sebelumnya. Maksud dari responden kunci adalah orang yang memiliki pengetahuan luas mengenai kegiatan perdagangan burung.
Responden tersebut ditujukan langsung kepada pedagang burung yang ada di kota ketapang yang dianggap dapat membantu melengkapi data.

Data primer merupakan data hasil pengamatan secara langsung diperoleh di lapangan melalui wawancara dengan masyarakat yang terlibat dalam perdagangan burung yang ada di Kota Ketapang yang dipilih sebagai responden dengan bantuan kuisioner dan survey lapangan. Pengumpulan data primer diperoleh dari lokasi penelitian meliputi pencatatan jenis burung dan melakukan wawancara kepada pelakupelaku yang terlibat dalam perdagangan burung seperti pemburu, penampung dan pedagang burung.

Data sekunder berupa kondisi umum lokasi pengambilan data yang diperoleh dari berbagai sumber terkait baik dari instansi, badan atau lembaga dan literatur selanjutnya dilakukan identifikasi jenis burung.

Analisa data yang dilakukan untuk menjelaskan data yang diperoleh dari lapangan dilakukan 2 tahap yaitu :

\section{Metode Deskriptif}

Metode Deskriptif merupakan metode dalam meneliti status sekelompok manusia, suatu objek, suatu set kondisi, suatu sistem pemikiran ataupun suatu kelas peristiwa pada masa sekarang. Tujuan dari penelitian deskriptif ini adalah untuk membuat deskripsi, faktual dan akurat mengenai fakta-fakta, sifat-sifat serta hubungan antar fenomena yang diselidiki terhadap pemanfaatan jenis burung (Nazir, 1998). Pendekatan kualitatif dalam penelitian 
ini dimaksudkan untuk menghasilkan data deskriptif berupa ucapan atau tulisan dan perilaku yang dapat diamati dari subjek itu sendiri, data tersebut kemudian dianalisis (Maleong, 2010).

Status Perlindungan

Status perlindungan adalah mengelompokan jenis burung dalam status keterancaman menurut IUCN (International Union For the Conservation of Nature and Natural Resources), Status perlindungan berdasarkan Peraturan Perdagangan Internasional menurut CITES, Status Perlindungan dalam Hukum Negara Republik Indonesia ditekankan pada perlindungan terhadap spesies burung tersebut. Untuk status perlindungan spesies menurut tata di Indonesia mengacu pada (A, UU No. 5/1990 tentang Konservasi Sumber Daya Alam Hayati dan Ekosistemnya; B, No. P. 106 / MENLHK / SETJEN/KUM.1 / 12 / 2018 tentang Jenis Tumbuhan dan Satwa yang Dilindungi.

\section{HASIL DAN PEMBAHASAN}

\section{Karaktristik Masyarakat}

Berdasarkan metode yang digunakan, jumlah responden yang dapat diwawancara adalah sebanyak 10 responden. Tabel 1 di bawah ini menggambarkan bahwa tingkat pendidikan resonden tergolong rendah. Frekuensi dan persentase disajikan pada tabel 1 di bawah ini.

Tabel 1. Karakteristik Menurut Tingkat Pendidikan dan Umur Responden (Characteristics by Respondents' Education and Age Levels)

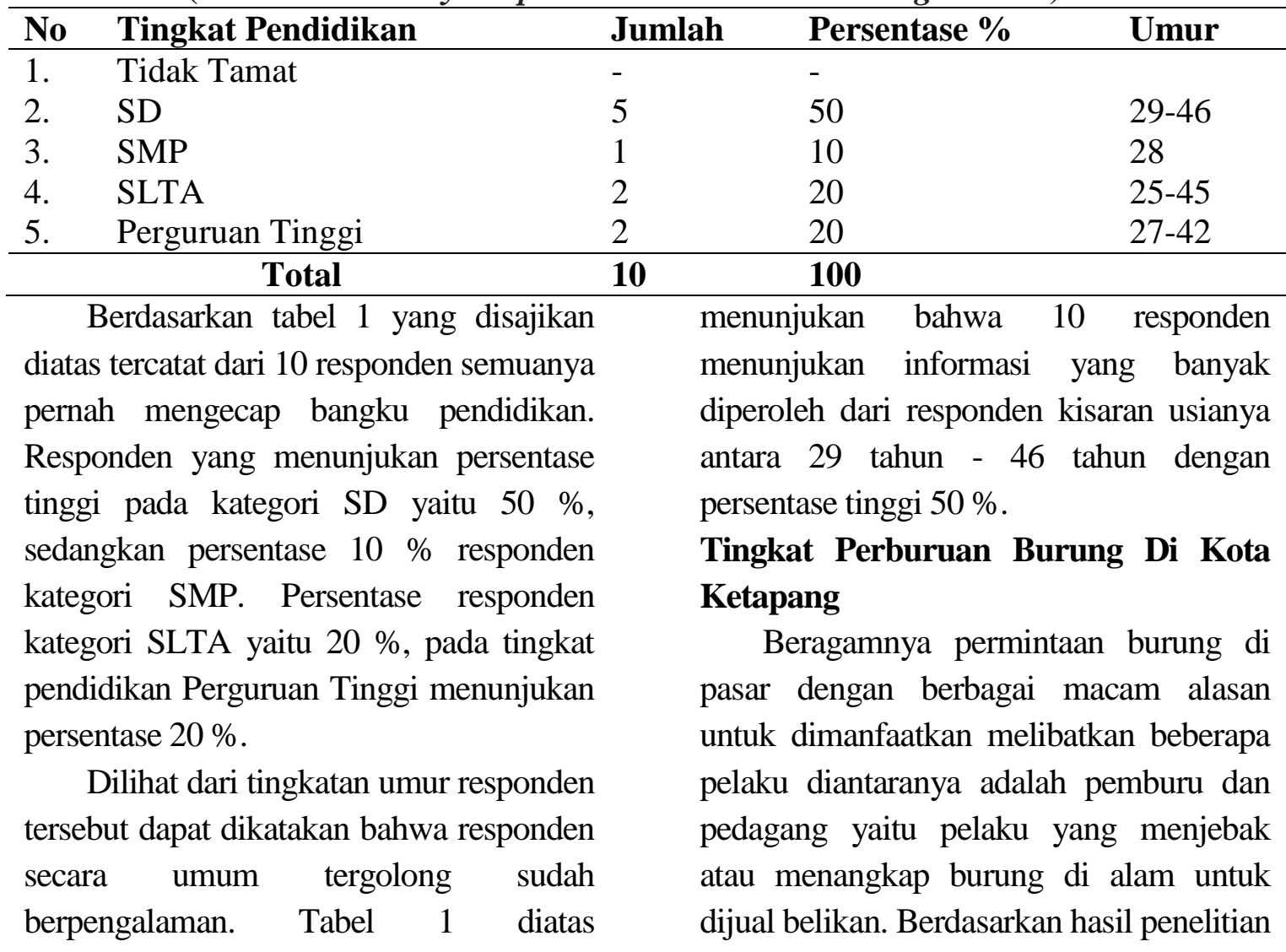


tingkat perburuan terdapat 2 responden yang melakukan kegiatan perburuan burung liar di alam dan 8 responden sebagai pedagang burung. pendapatan yang diperoleh hasil beburu burung liar di alam dalam 1 hari sebanyak 2 - 8 ekor untuk semua jenis. Burung yang ditangkap merupakan jenis burung yang diminati dari kicauanya dan memiliki nilai ekonomi yang tinggi beberapa diantaranya adalah jenis kacer (Copsychus saularis musicus) Rp. 150.000/ekor, murai batu (Copsychus malabaricus) Rp. 300.000/ekor, serindit (Loriculus galgulus) Rp. 20.000 - Rp. 50.000/ekor, kapas tembak (Criniger bres) Rp. 100.000/ekor, pentet (Lanius schach bentet) Rp. 80.000 - Rp. 100.000, cucak hijau (Chloropsis sonnerati) $\mathrm{Rp}$. 300.000/ekor, jalak (Acridotheres javanicus) Rp. 50.000/ekor, celilin (Platylophus galericulatus) Rp. 500.000/ekor serta kolibri (Anthreptes malacensis dan Anthreptes singalensis) Rp. 50.000/ekor. Diketahui hasil dari wawancara terhadap responden pelaku perburuan burung liar diperoleh gambaran lokasi perburuan yang menyatakan bahwa daerah asal tangkapan dan perkiraan jarak daerah asal penangkap yaitu Kecamatan Matan Hilir Selatan Desa Pesaguan (sungai kepuluk dan sungai tapah $\pm 5 \mathrm{~km}$ ), Kecamatan Muara Pawan Desa Tanjung Pasar dan Desa Ulak Medang $\pm 50 \mathrm{~km}$ dengan jarak tempuh \pm 1 jam, Kecamatan Matan Hilir Utara Desa Sungai Putri \pm 40 $\mathrm{km}$, Kecamatan Sandai $\pm 140 \mathrm{~km}$, dan Kecamatan Sungai Laur (Perbukitan Batu Daya $\pm 200 \mathrm{~km}$ ). Sebaran lokasi asal tangkapan burung liar dapat dilihat pada lampiran 1.
Berburu burung liar di alam dilakukan secara berkelompok, terdapat 7 kelompok dengan jumlah sebanyak 2 - 4 orang dalam 1 kelompok yang masih aktif dalam melakukan kegiatan berburu.

Waktu efektif pelaksanaan dalam kegiatan berburu biasanya dilakukan pada saat musim berbuah, musim kemarau dan musim kawin karena burung mudah ditangkap. Adapun waktu yang diperlukan untuk berburu sebanyak 2 - 3 kali dalam 1 minggu selama minimal 2 hari dilapangan pada saat 1 kali turun berburu. Adapun alat - alat perburuan yang digunakan oleh masyarakat adalah sebagai berikut:

a. Misnet atau Jala kabut (jaring)

b. Tongkat sepanjang \pm 20 meter

c. Jerat

d. Lem perekat

e. Pulut

f. Getah karet

g. HP/recorder

Dalam melakukan perburuan di lapangan terdapat beberapa cara dalam melaksanakan perburuan yaitu sebagai berikut :

a. Memasang jerat dengan menggunakan bambu dan tali rapia digunakan untuk jenis burung yang aktif di lantai hutan. Jerat dipasang dengan sengaja pada lokasi yang sering didatangi oleh burung, jerat digunakan untuk menangkap organ kaki pada saat burung menginjak “dudukan", kait terlepas dari tempat kait sehingga tali mengikat kaki.

b. Jebakan menggunakan lem perekat, pulut dan getah karet adalah jebakan memungkinkan burung yang tertangkap tidak akan mati. Lem 
perekat, pulut dan getah karet dioleskan pada ranting kayu, kemudian ranting tersebut diletakan dekat genangan air sehingga saat burung hendak minum bulu akan menempel atau dengan meletakan ranting pada umpan yang telah disediakan. Jebakan ini juga dapat dipancing dengan menggunakan HP recorder untuk menarik datangnya burung.

c. Memasang misnet atau jala kabut biasanya terbuat dari pukat nilon, jaring sepanjang 2 - 3 meter dengan tinggi 1,5 meter dipasang dan dibentangkan pada lokasi yang sering dilewati burung, ketika burung melewati jaring, tubuhnya tergulung ke dalam jaring tersebut.

d. Dengan cara ditangkap hidup dalam sarang untuk mengambil anakan

Banyaknya jumlah jebakan dalam sekali pasang ditentukan oleh frekuensi satwa yang sering dijumpai. Semakin banyak perjumpaan, pemasangan jebakan atau perangkap semakin meningkat. Pemilihan lokasi pemasangan jerat sesuai dengan burung sasaran, dan jarak antara jerat satu ke jerat yang lain dapat terjangkau oleh pemburu.

Tingkat perdagangan burung Di Kota Ketapang

Pada Kota Ketapang penelitian terdapat 8 toko burung tersebar di beberapa tempat penjualan, jumlah ini termasuk pedagang yang menjual pakan dan aksesories sarana prasarana pemeliharaan burung (sangkar, pakan, obat, vitamin, dan lainnya), tempat penjualan seperti toko, kios di pinggiran jalan. Jenis burung yang diperoleh dari hasil penelitian toko burung di Kota Ketapang sangatlah beragam. Tercatat sebanyak 31 jenis burung yang bervariasi harga penjualannya, dapat dilihat pada tabel 2. Toko yang paling banyak menjual burung adalah toko burung Ucok sebanyak 98 ekor, toko burung Portugal sebanyak 62 ekor, toko Amad 57 ekor, toko Sera 22 ekor, toko Iman 12 ekor, dan toko burung penjualan yang terkecil adalah toko Rumah Jangkrik yaitu 8 ekor, toko burung Bintang Aquarium 5 ekor, toko burung Phoenix Aquarium 3 ekor. 
Tabel 2. Total Jenis Burung Yang Diperdagangkan Di Kota Ketapang (Total Bird Type Traded in Ketapang City)

\begin{tabular}{|c|c|c|c|c|}
\hline \multirow{2}{*}{ No } & \multicolumn{2}{|c|}{ Jenis } & \multirow{2}{*}{ Jumlah } & \multirow{2}{*}{$\begin{array}{c}\text { Harga Rata-rata } \\
\text { (Rp) }\end{array}$} \\
\hline & Nama Ilmiah & Nama Lokal & & \\
\hline 1. & Acridotheres javanicus & Jalak & 4 & 50.000 \\
\hline 2. & Acridotheres tristis & Jalak nias & 3 & 700.000 \\
\hline 3. & Agapornis sp & Love bird & 10 & 1.100 .000 \\
\hline 4. & Anthreptes malacensis & Kolibri & 1 & 100.000 \\
\hline 5. & Aplonis panayensis & Perling & 1 & 90.000 \\
\hline 6. & Chalcoparia singalensis & Kolibri & 5 & 50.000 \\
\hline 7. & Chloropsis sonnerati & Cucak hijau & 8 & 500.000 \\
\hline 8. & Columba domestica & Merpati & 10 & 100.000 \\
\hline & Copsychus malabaricus & Murai batu & 44 & 200.000 \\
\hline & Copsychus saularis musicus & Kacer & 50 & 1.320 .000 \\
\hline & Criniger bres & Kapas tembak & 15 & 400.000 \\
\hline 12. & Dendrocopus canicapillus & Pelatuk & 1 & 50.000 \\
\hline 13. & Dinopium javanense & Pelatuk bawang & 1 & 200.000 \\
\hline 14. & Ixos malaccensis & Siri-siri & 1 & 200.000 \\
\hline 15. & Lanius schach bentet & Pentet & 13 & 650.000 \\
\hline 16. & Loriculus galgulus & Serindit & 44 & 920.000 \\
\hline 17. & Melopsittacus undulates & Parkit & 2 & 150.000 \\
\hline 18. & Padda oryzivora & Glatik & 1 & 50.000 \\
\hline & Parus major & Glatik & 5 & 250.000 \\
\hline & Phaenicophaeus sumatranus & Kadalan saweh & 1 & 400.000 \\
\hline & Platylophus galericulatus & Celilin & 2 & 1.375 .000 \\
\hline & Prinia familiaris & Ciblek & 3 & 650.000 \\
\hline & Pycnonotus aurigaster & Kutilang & 3 & 50.000 \\
\hline & Pycnonotus goiavier & Merbah cerukcuk & 1 & 50.000 \\
\hline 25 . & Pycnonotus zeylanicus & Cucak rowo & 1 & 7.000 .000 \\
\hline & Serinus canaria & Kenari & 17 & 2.600 .000 \\
\hline & Geopelia Striata & Perkutut & 5 & 200.000 \\
\hline & Streptopelia dusumieri & Putar & 6 & 50.000 \\
\hline & Sturnus contra & Jalak suren & 2 & 1.000 .000 \\
\hline & Sturnus philippensis & Kepodang & 1 & 1.000 .000 \\
\hline & Zosterops everetti & Pleci & 6 & 350.000 \\
\hline & Total & & 267 & 21.805.000 \\
\hline
\end{tabular}

Dari tabel diatas, dapat diketahui hasil dari penelitian toko burung di Kota Ketapang yaitu jumlah individu 267 dari 31 jenis burung dengan total harga rata-rata Rp. $\mathbf{2 1 . 8 0 5 . 0 0 0 .}$ Sebagian besar jenis burung ini merupakan tangkapan alam daerah asal Kabupaten Ketapang Kalimantan Barat. Hal ini dikarenakan tingginya aktivitas perburuan burung liar di alam untuk memenuhi permintaan konsumen. Perburuan dan perdagangan burung merupakan masalah utama yang dapat mengancam keberadaan jenis maupun populasi burung di alam. Diketahui dari hasil penelitian terdapat 3 jenis dengan jumlah pengambilan terbesar dari alam yang paling banyak diperdagangkan yaitu jenis kacer (Copsychus saularis) sebanyak 50 ekor/individu, murai batu (Copsychus malabaricus) dan serindit (Loriculus galgulus) sebanyak 44 ekor/individu. Keadaan ini mengungkapkan kenyataan bahwa ketiga jenis ini telah menjadi komoditas ekonomi dengan permintaan pasar yang kuat, setidaknya untuk kebutuhan lokal. Hampir semua jenis yang 
diperdagangkan adalah jenis yang dinikmati suara kicauanya. Jenis dengan tingkat terkecil yang diperdagangkan dengan harga yang paling tinggi adalah cucak rowo (Pycnonotus zeylanicus) dengan harga Rp. 7.000.000/ekor. Variasi dan kisaran harga jenis burung ditentukan oleh pedagang berdasarkan karakteristik burung yang bersangkutan. Faktor-faktor yang sangat berpengaruh pada jenis burung adalah keindahan suaranya, keindahan warna bulunya, dan jenis kelaminnya. Kelebihan jenis burung tertentu untuk faktor-faktor diatas merupakan sesuatu yang dapat memuaskan masyarakat (konsumen) dalam memeliharanya. Di samping itu, jenis cucak rowo (Pycnonotus zeylanicus) juga sudah semakin sulit ditemukan dialam bebas. Kondisi ini ditemukan hanya 1 ekor di toko. Hal ini kemungkinan besar disebabkan karena tekanan terhadap jenis dan poulasinya akibat perburuan yang tidak terkendali di habitat aslinya.

\section{Status Konservasi Burung}

Berdasarkan dari 31 jenis burung yang diperdagangkan di Kota Ketapang, secara keseluruhan tergolong kedalam 15 suku (family). Diantaranya 9 jenis burung termasuk dalam kategori dilindungi menurut Undang-undang, CITES (Convention on International Trade of Endangered Species of Wild Fauna and Flora), dan IUCN (International Union for Conservation of Nature and Natural Resources) dapat dilihat pada tabel 3 .

Menurut UU No. 5/1990, No. P. 106 / MENLHK / SETJEN/KUM.1 / 12 / 2018 tentang Jenis Tumbuhan dan Satwa yang Dilindungi, terdapat 3 jenis burung termasuk kedalam jenis dilindungi yaitu Cucak hijau (Chloropsis sonnerati), Serindit (Loriculus galgulus), Celilin (Platylophus galericulatus). Selanjutnya 3 jenis burung termasuk dalam status perlindungan menurut CITES yaitu mengelompokan kategori-kategori jenis dalam appendix 2 (jenis yang statusnya belum terancam tetapi akan terancam punah apabila diekploitasi berlebihan) yaitu Serindit (Loriculus galgulus), Glatik (Padda oryzivora), Cucak rowo (Pycnonotus zeylanicus). Staus keterancaman menurut IUCN terdapat 8 jenis burung diantaranya 4 jenis berstatus $\mathrm{VU}=$ Vulnerable (terancam) yaitu Jalak (Acridotheres javanicus), Cucak hijau (Chloropsis sonnerati), Glatik (Padda oryzivora), Putar (Streptopelia dusumieri). 3 jenis berstatus NT = Near Threatened (mendekati terancam) yaitu, Siri-siri (Ixos malaccensis), Kadalan saweh (Phaenicophaeus sumatranus), Celilin (Platylophus galericulatus) dan 1 Jenis yang berstatus $\mathrm{EN}=$ Endangered (terancam punah) yaitu Cucak rowo (Pycnonotus zeylanicus). 
Tabel 3. Jenis Burung Yang Di Perdagangkan Berdasarkan Suku (Family) dan Status Konservasinya di Kota Ketapang (Trade Bird Species Based On Taxonomy family and Conservation Status)

\begin{tabular}{|c|c|c|c|c|c|c|c|c|}
\hline \multirow{2}{*}{ No } & \multirow{2}{*}{ Family } & \multicolumn{2}{|c|}{ Jenis } & \multicolumn{3}{|c|}{ Status Konservasi } & \multicolumn{2}{|c|}{ Keterangan } \\
\hline & & Nama Ilmiah & Nama Lokal & ${ }^{1}$ IUCN & ${ }^{2}$ CITES & ${ }^{3} \mathbf{P P}$ & Liar & Ternak \\
\hline 1 & Chloropseidae & Acridotheres javanicus & Jalak & VU & & & $\checkmark$ & \\
\hline 2 & Cisticolidae & Acridotheres tristis & Jalak nias & & & & $\checkmark$ & \\
\hline 3 & Columbidae & Agapornis sp & Love bird & & & & & $\checkmark$ \\
\hline 4 & Columbidae & Anthreptes malacensis & Kolibri & & & & $\checkmark$ & \\
\hline 5 & Columbidae & Aplonis panayensis & Perling & & & & $\checkmark$ & \\
\hline 6 & Cuculidae & Anthreptes singalensis & Kolibri & & & & $\checkmark$ & \\
\hline 7 & Estrildidae & Chloropsis sonnerati & Cucak hijau & VU & & $\mathrm{AB}$ & $\checkmark$ & \\
\hline 8 & Fringillidae & Columba domestica & Merpati & & & & & $\checkmark$ \\
\hline 9 & Laniidae & Copsychus malabaricus & Murai batu & & & & $\checkmark$ & \\
\hline 10 & Muscicapidae & $\begin{array}{l}\text { Copsychus saularis } \\
\text { musicus }\end{array}$ & Kacer & & & & $\checkmark$ & \\
\hline 11 & Muscicapidae & Criniger bres & Kapas tembak & & & & $\checkmark$ & \\
\hline 12 & Nectariniidae & $\begin{array}{l}\text { Dendrocopus } \\
\text { canicapillus }\end{array}$ & Pelatuk & & & & $\checkmark$ & \\
\hline 13 & Nectariniidae & Dinopium javanense & Pelatuk bawang & & & & $\checkmark$ & \\
\hline 14 & Paridae & Ixos malaccensis & Siri-siri & NT & & & $\checkmark$ & \\
\hline 15 & Picidae & Lanius schach bentet & Pentet & & & & $\checkmark$ & \\
\hline 16 & Picidae & Loriculus galgulus & Serindit & & II & $\mathrm{AB}$ & $\checkmark$ & \\
\hline 17 & Platylophidae & Melopsittacus undulates & Parkit & & & & & $\checkmark$ \\
\hline 18 & Psittacidae & Padda oryzivora & Glatik & VU & II & & $\checkmark$ & \\
\hline 19 & Psittacidae & Parus major & Glatik & & & & $\checkmark$ & \\
\hline 20 & Psittacidae & $\begin{array}{l}\text { Phaenicophaeus } \\
\text { sumatranus }\end{array}$ & Kadalan saweh & NT & & & $\checkmark$ & \\
\hline 21 & Pycnonotidae & $\begin{array}{l}\text { Platylophus } \\
\text { galericulatus }\end{array}$ & Celilin & NT & & $\mathrm{AB}$ & $\checkmark$ & \\
\hline 22 & Pycnonotidae & Prinia familiaris & Ciblek & & & & & $\checkmark$ \\
\hline 23 & Pycnonotidae & Pycnonotus aurigaster & Kutilang & & & & $\checkmark$ & \\
\hline 24 & Pycnonotidae & Pycnonotus goiavier & Merbah cerukcuk & & & & $\checkmark$ & \\
\hline 25 & Pycnonotidae & Pycnonotus zeylanicus & Cucak rowo & EN & II & & $\checkmark$ & \\
\hline 26 & Sturnidae & Serinus canaria & Kenari & & & & & $\checkmark$ \\
\hline 27 & Sturnidae & Geopelia Striata & Perkutut & & & & $\checkmark$ & \\
\hline 28 & Sturnidae & Streptopelia dusumieri & Putar & VU & & & & $\checkmark$ \\
\hline 29 & Sturnidae & Sturnus contra & Jalak suren & & & & $\checkmark$ & \\
\hline 30 & Sturnidae & Sturnus philippensis & $\begin{array}{l}\text { Kepodang/Jalak } \\
\text { Filipina }\end{array}$ & & & & $\checkmark$ & \\
\hline 31 & Zosteropidae & Zosterops everetti & Pleci & & & & $\checkmark$ & \\
\hline & & Total & & 8 & 3 & 3 & 24 & 7 \\
\hline
\end{tabular}

Keterangan:

${ }^{1}$ IUCN Redlist Database (International Union Conservation of Nature and Natural Resources);

${ }^{2}$ CITES (Convention on International Trade of Endangered Wildlife Flora and Fauna);

${ }^{3}$ PP (Peraturan Pemerintah (A, UU No. 5/1990 tentang Konservasi Sumber Daya Alam Hayati dan Ekosistemnya; B, No. P. 106 / MENLHK / SETJEN/KUM.1 / 12 / 2018 tentang Jenis Tumbuhan dan Satwa yang Dilindungi.

\section{Kesimpulan}

Diketahui jenis burung yang diperdagangkan di Kota Ketapang terdapat 267 individu dari 31 jenis burung. Tergolong kedalam 15 suku (family), terdapat 11 jenis yang dilindungi. Diantaranya 3 jenis burung termasuk dalam kategori dilindungi menurut Undang-undang, 3 jenis burung dikatagori CITES (Convention 
on International Trade of Endangered Species of Wild Fauna and Flora), dan 8 jenis dikatagori IUCN (International Union for Conservation of Nature and Natural Resources).

\section{Saran}

Diperlukan penelitian burung lanjutan secara rutin untuk melakukan pemantauan burung liar yang diperdagangkan baik di Kota Ketapang Kalimantan Barat maupun lokasi lainnya, sehingga data dan informasi burung-burung yang diperdagangkan dapat diketahui. Perlu adanya upaya untuk melestarikan populasi burung liar di alam dengan melakukan peningkatan kesadaran masyarakat, pembatasan perburuan dan pelarangan terhadap burung yang populasinya sedang kritis atau terancam jumlahnya. Perhatian untuk menjamin kelestarian satwa liar burung dengan usaha penangkaran.

\section{Daftar Pustaka}

Bernad, H. 2002. Research Methods in Antropology: Qualitative and Quantitative Methods, Third edition, Altamitra Press, Walnut Creek, California.

Maleong, L, J. 2010. Metode Penelitian Kualitatif. Remaja Rosdakarya, Bandung.

Nazir, Moh, 1988. Problematika Penulisan Cerita Rakyat. Jakarta. Balai Pustaka, hal. 295.

Nellemann, C., Henriksen, R., Raxter, P., Ash, N. and Mrema, E (Eds). (2014). The Environmental Crime
Crisis-Threaats to sustainable Development from Illegal Exploitation and Trade in Wildlife and Forest Resources. A UNEP Rapid Response Assessment. United Nations Environment Programmme and GRID-Arendal, Nairobi and Arendal.

Nijman, V. 2010. An overview of international wildlife trade from Southeast Asia. Biodiversity and Conservation 19(4): 1101-1114.

Nijman, V., Shepherd, C.R., Mumpuni and Sanders, K. L,. 2012. Overexploitation and illegal trade of retiles in Indonesia. Herpetological Journal 22:83-89.

P. 106 / MENLHK / SETJEN/KUM.1 / 12 / 2018 tentang Jenis Tumbuhan dan Satwa yang Dilindungi

PP No. 7/1999. Pengawetan Jenis Tumbuhan dan Satwa. Jakarta.

PP No. 8/1999. Pemanfaatan Jenis Tumbuhan dan Satwa Liar. Jakarta.

Shepherd, C.R 2006. The bird trade in Medan, North Sumatra: an overview. BirdingASIA 5:16-24.

Stengel, C.J., Shepherd, C.R. and Caillabet, O.S. 2011. The trade in tortoise and freshwater turtle in jakarta, Indonesia revisited. TRAFFIC Southeast Asia, Petaling Jaya, Selangor, Malaysia.

UU No. 5/1990 tentang Konservasi Sumber Daya Alam Hayati dan Ekosistemnya. Jakatra. 
JURNAL HUTAN LESTARI (2019)

Vol. 7 (1) : 237 - 247

Lampiran I. Sebaran lokasi asal tangkapan burung liar di kabupaten ketapang (Distribution of locations for Trap wild birds in Ketapang District)

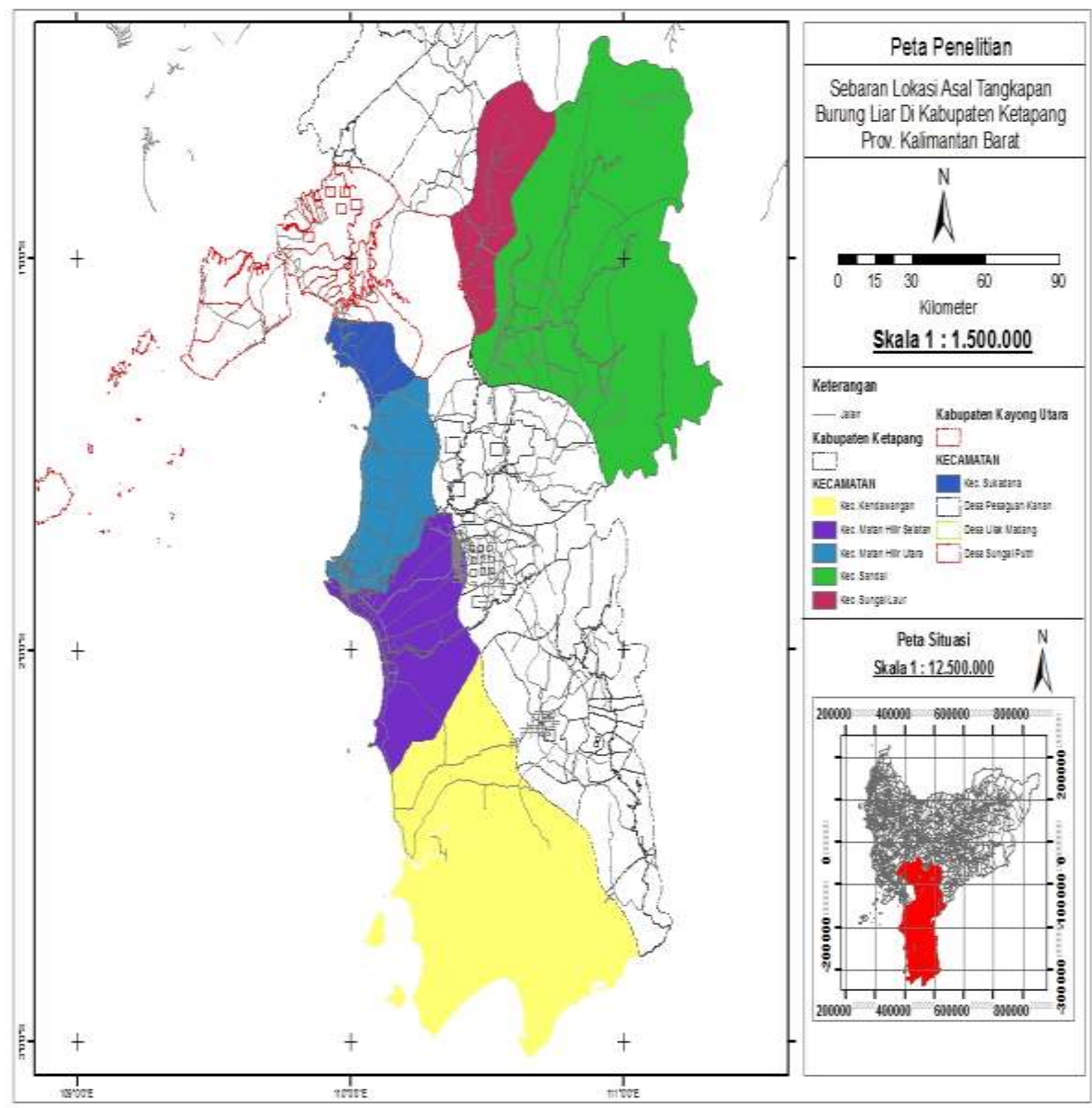

